\title{
Teachers' Opinions about the Effect of Chemistry Demonstrations on Students' Interest and Chemistry Knowledge
}

Luka Vinko ${ }^{\star 1}$, Seamus Delaney ${ }^{2}$ and Iztok DevetaK ${ }^{3}$

$\approx$ Chemistry is an experimental discipline that uses experimentation as one of its most important research methods. Laboratory work and other practical work are therefore also essential in chemistry lessons. Chemistry demonstrations are used by teachers as an educational approach that can increase students' interest in chemistry and motivate them to learn chemical concepts with understanding. However, if the students are actively involved in the chemistry demonstration, it can be just as effective as or even more effective than students' learning through experiments. The purpose of this research is to examine teachers' opinions about the impact of chemistry demonstrations on students' interest and chemistry knowledge. Based on a quantitative research approach, 81 primary and secondary school teachers from different regions of Slovenia participated in this study. Participating teachers completed an online questionnaire on their perceptions of the impact of chemistry demonstrations on students' interest and performance in chemistry classes and on the quality of students' knowledge of chemistry. The results show that regardless of the years of teaching experience and the frequency of performing chemistry demonstrations, the participating teachers consider such demonstrations to have a positive effect on the motivation and performance of the students in chemistry and on the quality of the students' knowledge of chemistry.

Keywords: chemical concepts understanding, chemistry demonstrations, chemistry teaching, students' interest

$1 \quad{ }^{\star}$ Corresponding Author. Faculty of Education, University of Ljubljana, Slovenia; luka.vinko@pef.uni-lj.si.

2 Faculty of Arts and Education, Deakin University, Australia.

3 Faculty of Education, University of Ljubljana, Slovenia. 


\section{Mnenje učiteljev o učinkih demonstracijskih eksperimentov na interes učencev in njihovo kemijsko znanje}

Luka Vinko, Seamus Delaney in Iztok Devetak

$\sim$ Kemija je eksperimentalna veda, ki uporablja eksperiment kot eno glavnih orodij preučevanja. Laboratorijsko in drugo praktično delo sta tako bistvena tudi pri kemijskem izobraževanju. Demonstracijske eksperimente učitelji uporabljajo kot pedagoški pristop, ki lahko povečuje učenčev interes za kemijo pa tudi motivira učence za učenje z razumevanjem. Če so učenci v demonstracijo aktivno vključeni, pa so lahko demonstracijski eksperimenti enako učinkoviti oziroma še učinkovitejši kot samostojno eksperimentiranje učencev. Namen raziskave je bil preučiti mnenja učiteljev o učinkih demonstracijskih eksperimentov na učenčev interes in uspešnost pri pouku kemije ter na kakovost učenčevega kemijskega znanja. $\mathrm{V}$ raziskavi, ki je temeljila na kvantitativnem raziskovalnem pristopu, je sodelovalo 81 osnovnošolskih in srednješolskih učiteljev iz različnih statističnih regij Slovenije. Učitelji so izpolnili spletni vprašalnik, ki se je navezoval na njihovo mnenje o učinkih izvajanja demonstracijskih eksperimentov na interes učencev in uspešnost pri pouku kemije ter na kakovost učenčevega kemijskega znanja. Ugotovljeno je bilo, da učitelji ne glede na delovno dobo in pogostost izvajanja demonstracijskih eksperimentov po večini menijo, da demonstracijski eksperimenti pozitivno vplivajo na interes in uspešnost učencev pri pouku kemije ter na kakovost učenčevega kemijskega znanja.

Ključne besede: razumevanje kemijskih pojmov, demonstracijski eksperimenti, poučevanje kemije, interes učencev 


\section{Introduction}

The experiment is one of the most important research methods in chemistry. Laboratory work and other practical work are, therefore, also essential in chemistry lessons (Tsaparlis, 2009), which can also be observed in primary and secondary school curricula, which are mainly based on activities at the macroscopic level, indicating that students need to understand chemistry as an experimental discipline (Wissiak Grm \& Glažar, 2002). However, the macroscopic level of chemistry is an essential component for students to understand the submicroscopic (particulate) and symbolic levels of chemical concepts (Pavlin, Glažar, Slapničar, \& Devetak, 2019). Practical work includes activities in which students handle substances and materials in order to carry out a certain chemical reaction or observe chemistry demonstrations (Hodson, 1990). The basic goal of these activities is to learn new chemical concepts. Chemistry demonstrations are usually conducted by teachers or experts who can provide the best quality demonstration for students. The latter should participate as active learners and acquire knowledge experientially. The advantage of chemistry demonstrations is that teachers have greater control over the overall work arrangement of the experiment and can focus students' attention on the most important parts of the experiment (Johnston \& Al-Shuaili, 2001).

This paper aims to determine the opinions of Slovenian chemistry teachers on how the use of chemistry demonstrations in chemistry lessons influences the students' interest in chemistry and their performance. The term 'chemistry demonstrations' is used for the purposes of this paper when the teacher's experimental work performed in front of the whole class is discussed.

\section{Practical work}

When we speak of practical work, we usually speak of activities where students observe or work with objects and materials (individually in pairs or in groups) or observe teacher demonstrations (Hofstein, 2015). Practical work includes not only work in a real chemistry laboratory, but also any activity involving tangible objects that enable students to handle and interact with substances, such as dissolving sodium chloride in water. By stimulating interest and enjoyment, practical work motivates students, teaches them laboratory skills, improves their learning of science, gives them insight into scientific methods and develops scientific reasoning, such as objectivity and open-mindedness (Hodson, 1990). Practical or experimental work emphasises students' understanding of the nature of science, for which it is not enough to learn the facts by rota, but it is also a dynamic process of finding different ways to explain natural phenomena (Hodson, 1993). 
It can be said that experiments and practical work play a central role in science teaching; in most cases, both teachers and students have a very positive attitude towards practical work, especially because they 'like to experiment'. From the perspective of science teaching, experiments can contribute to various aspects of science learning, but they are usually used in everyday science teaching for a limited number of goals (Haagen-Schützenhöfer \& Joham, 2018).

\section{Chemistry demonstrations}

Teachers use chemistry demonstrations as a pedagogical approach that not only increases students' interest in chemistry but also motivates them to learn with understanding (Bodner, 2001; Beall, 1996; Buncick, Betts, \& Horgan, 2001; Zimrot \& Ashkenazi, 2007). Despite the students' opinion that chemistry demonstrations are not as effective as active individual hands-on experimental work, we should not ignore the fact that students who perform experiments individually often focus on unimportant parts of the experiment while neglecting to focus on other more meaningful parts.

The advantage of chemistry demonstrations is that the teacher has more control over the course of the experiment and can thus direct the students' concentration to the important parts of the experiment (Johnstone \& Al-Shuaili, 2001). White (1996) found that chemistry demonstrations can be as effective as individual hands-on experimental work if the students are actively involved in the demonstration (they observe, write down the results, complete tasks related to the experiments, etc.). Logar and Ferk Savec (2011) also concluded that chemistry demonstrations are more effective in terms of students' long-term knowledge than students' hands-on experimental work.

When conducting a chemistry demonstration, we have the power to decide whether the experiment will be trivial and fun or whether it will serve to actually show and explain a particular chemical concept (Meyer, Schmidt, Nozawa, \& Panee, 2003). The teacher must not only choose the right experiment to explain a particular chemistry concept but must also take into account that it is suitable for students according to their age and previous chemical knowledge and that it is relatively easy and not too expensive to perform (Trowbridge, Bybee, \& Powell, 200o).

In choosing the appropriate experiment, one must consider how to carry out the demonstration and show it to the students to make them think about what they have seen, and one should draw appropriate conclusions to learn new concepts (Kelter, 1994). The teacher must perform the experiment at least once before presenting it to the students. In this way, he/she can strengthen his/her skills and at the same time consider how to explain what happens during the demonstration in order to effectively present the desired chemical concept to students (Moore, 2000). 
Thorough preparation for the demonstration allows the teacher to devote time to the students and guide the learning process during the demonstration. Teachers have two roles in conducting a demonstration. Not only do they have to carry out a particular experiment, but they also have to take special care that all students clearly observe the course of the experiment. The teacher should also direct their attention and attempt to involve the students in the chemical process to be demonstrated. In this sense, experiments can be both educational and entertaining. By actively participating in the demonstration, students learn much more than usual (Logar \& Ferk Savec, 2011; Waldman, Schechinger, \& Nowick, 1996).

Chemistry demonstrations bring important experiences with them, which can be a topic of discussion for over-generalised and simple chemical concepts. The design of such demonstrations begins with the evaluation of the students' knowledge and the exploration of specific contexts by the teachers in which he or she places certain chemistry demonstrations. These contexts can then be useful discussion topics for chemistry lessons (Ashkenazi \& Weaver, 2007).

In order to involve students more actively in the demonstrations, Chamely-Wiik, Haky, Louda, and Romance (2014) proposed a specific SQER 3 model (survey, question, experiment, recite, reflect, review) that provides guidelines for the development of quality demonstrations. This model consists of several steps: 1) Survey: focuses on key concepts and basic questions that arise during the demonstration; 2) Question: students develop a testable question based on observations and prior knowledge; 3) Experiment: students and teachers develop an experiment to answer the question, make observations and collect data; 4) Reciting: students organise the data and verbalise the results; 5) Reflecting: students explain the results and develop additional questions needed to understand the concepts; 6) Reviewing: teachers and students review the key concepts and apply them to new situations. The SQER 3 model can be easily used for most demonstrations, allowing for the flexible design and execution of chemistry demonstrations.

\section{Research problem and research questions}

Based on the results of the national evaluation of chemical knowledge at the end of compulsory education (9th grade, average age of students 14 years), it can be concluded that students have problems in solving tasks involving experimental work. After the literature review, the research problem was defined to be how demonstration experiments affect the students' motivation, their performance in chemistry lessons, and their chemical knowledge. Based on this research problem, four research questions were formed:

1. How do teachers involve their students in conducting chemistry demonstrations? 
2. Do chemistry teachers evaluate the impact of chemistry demonstrations on students' performance and interest in learning chemistry significantly differently?

3. Do chemistry teachers with different lengths of teaching experience have significantly different opinions about the impact of chemistry demonstrations on students' knowledge of chemistry?

4. Do chemistry teachers who conduct a varying number of chemistry demonstrations in their classes evaluate the impact of chemistry demonstrations on student performance and interest in chemistry education significantly differently?

\section{Method}

\section{Participants}

Teachers of the lower secondary school (students aged 12 to 14) and the upper secondary school (students aged 15 to 18 ) in service chemistry teachers participated in this research. The teachers were randomly selected from all statistical regions (Figure 1) of Slovenia according to the database provided by the Ministry of Education, Science and Sport. A total of 81 in-service teachers (57 lower secondary elementary and 24 upper secondary school chemistry teachers) were selected for research. They participated voluntarily in this study.

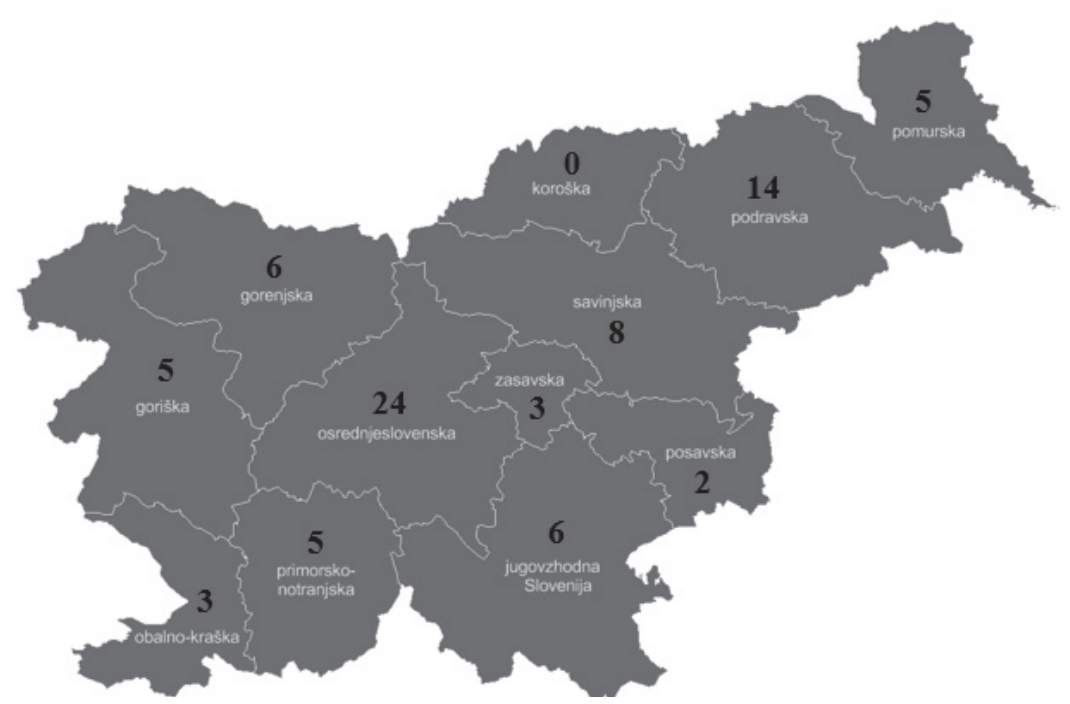

Figure 1: Distribution of participating teachers by Slovenian statistical regions. 
Table 1

The number of teachers in the specific age group.

\begin{tabular}{ll}
\hline Teachers' age in years & $n$ \\
\hline 56 or more & 11 \\
$46-55$ & 29 \\
$36-45$ & 27 \\
$26-35$ & 12 \\
25 or less & 2 \\
\hline Sum & 81 \\
\hline
\end{tabular}

The majority of teachers in the sample were between 36 and 55 years old $(69 \%)$.

Table 2

The number of teachers by years of teaching experience.

\begin{tabular}{lc}
\hline Years of teaching experience & $\boldsymbol{n}$ \\
\hline More than 15 & 50 \\
$11-15$ & 14 \\
$6-10$ & 8 \\
$2-5$ & 6 \\
Teaching the first year & 3 \\
\hline Sum & 81 \\
\hline
\end{tabular}

More than $60 \%$ of all teachers participating in this study had more than 15 years of practical experience in teaching chemistry in lower and upper secondary schools.

\section{Instrument}

The instrument was an online questionnaire co-developed with researchers from Deakin University in Australia as part of an international project: 'Interactive Demonstration Experiments combining macro observations with sub-micro observations - Teacher's explanation and student activity' The questionnaire included an introductory section on the demographic variables of teachers (e.g., age, experience in teaching chemistry. etc.) and three parts on teachers' approaches to teaching chemistry with chemistry demonstrations: 1) student participation in chemistry demonstrations (1 question), 2) teacher's opinion on how chemistry demonstrations affect student motivation 
(4 questions) and () teacher's opinion on how chemistry demonstrations affect student's chemistry knowledge (4 questions). The question from the first content block was an open question type; the other questions were based on the 5-point Likert scale.

\section{Research design}

The research was carried out as part of an international project linking three countries and three universities: Deakin University, Australia, Tallinn University, Estonia and the University of Ljubljana, Slovenia. The project was led by researchers from Australia, who also drafted the questionnaire in English. Comments and additions were submitted by the partner institutions, and the final form of the instrument was drawn up on this basis. The questionnaire was then translated into Slovenian and checked by three experts in the field of chemical education, which ensured the validity of the translation. Deakin University Qualtrics project managers provided computer support for the implementation of the Slovenian version of the online questionnaire. For the purposes of this paper, only data from Slovenian chemistry teaches has been used.

The instrument was sent out in two phases by e-mail to all selected teachers, as it was not possible to reach a sufficiently large sample in all national regions in just one phase. Prior to this, all teachers received an electronic note describing the study. After sending a reminder with a link to the online questionnaire to a total of 130 schools, it was completed by 81 teachers. The data were exported from an online database into an Excel and SPSS file. Descriptive and interferential statistics were used to process the data. Because of the nonnormal data distribution, non-parametric (Wilcoxon and Kruskal-Wallis) tests were used. The answers to the open questions were analysed and divided into different categories.

\section{Results and discussion}

The results are presented with regard to the research questions mentioned above.

The first research question was: 'How do teachers involve their students in conducting chemistry demonstrations?'; for that, the aim was to determine what the students do while the teachers are conducting chemistry demonstrations and also what the teachers expect their students to do during a demonstration; 73 teachers gave one or more answers. The answers were categorised and are presented in a frequency table. The answers, which appeared only once or twice, were left in the same form as they were written by the teachers. 
Table 3

Possibilities for involving students in demonstration experiments.

\begin{tabular}{lc}
\hline Participation of the students in demonstration experiments & $f$ \\
\hline Students observe the experiment. & 61 \\
They comment on and explain the observations. & 33 \\
They write down the observations. & 22 \\
You write conclusions based on observations / you connect the observations with the theory & 18 \\
They predict the course of the experiment. & 12 \\
They ask questions. & 12 \\
They answer questions. & 11 \\
They participate in the execution of the experiment. & 10 \\
The completed worksheets. & 7 \\
You draw the sketch of the experimental apparatus. & 7 \\
You write down the chemical reaction equation. & 5 \\
Other. & 35 \\
\hline
\end{tabular}

According to the categories, teachers want their students to write down, comment on and/or explain the observations $(f=73)$, followed by the students who observe the chemistry demonstrations $(f=61)$. Twenty-three teachers encourage their students to ask or answer questions about chemistry demonstrations, and 12 teachers want their students to predict the course of experiments before the chemistry demonstration. Ten of them ask their students to take part in the chemistry demonstration. Less than ten teachers involve their students in chemistry demonstrations by having them fill out worksheets, draw a sketch of the experimental apparatus and write down the chemical reaction equation.

Under the category 'other', 35 answers from teachers were categorised according to the frequency of their occurrence. The answers, which appeared twice, were: 'They write down a list of the chemicals used in the demonstration'; 'describe the laboratory equipment'; 'discuss safety precautions'; 'think about what's happening with reactants and products'; 'comment on results'; 'make hypotheses'; 'listen to the teacher's explanation'. The answers that appeared only once were as follows: 'they learn how to handle hazardous substances'; 'they learn chemical techniques'; 'they carry out the experiment themselves'; 'they point out the constants and variables'; 'they highlight key concepts that are captured by a chemical reaction'; 'analyse the execution of the experiment'; 'suggest possible improvements of the experiment'; 'try to make the demonstration experiment appropriate in different subject areas'; 'search for solutions'; 'enhance the experiment with their ideas'; 'participate in planning the chemistry demonstration'; 'plan the 
necessary protection'; 'solve tasks related to the experiment'; 'try to transfer the acquired knowledge to new cases'; 'record the experiment with a mobile phone'; 'write down questions'; 'test whether there has been a change in temperature'.

Similar results were found by Price and Brooks (2012): teachers explained that they involve students in experimental activities by instructing them to observe the course of the experiment actively. Some teachers invite students to predict the outcome of the experiment or instruct them to participate in it, while others ask them questions during the experiment that lead them to conclusions. Walton (2002) researched first-year chemistry students and found that a good way to engage his students was to have them write their observations on worksheets and then pass them on to their colleagues to evaluate the written observations and conclusions. It was also found that about $25 \%$ of teachers involve their students by telling them to write down their observations and draw conclusions from them. Ashkenazi and Waever (2007) found that students learn best when the teacher asks them to predict the results of the experiment in advance, consult with their neighbour and report their predictions.

The second research question was: 'Do chemistry teachers evaluate the impact of chemistry demonstrations on students' performance and interest in learning chemistry significantly differently?' and, in this context, the answers to four items from the questionnaire were totalled to determine the teachers' opinion about the impact of chemistry demonstrations on students' performance in chemistry and their impact on students' interest in it. Teachers expressed their opinions on the impact of chemistry demonstrations on the quality of the homework done, the practical work of the students, and the results of the students' knowledge tests.

Table 4

Teachers' opinions on the effects of demonstration experiments.

\begin{tabular}{lccccc}
\hline & $\boldsymbol{N}^{*}$ & Me & IQR & $\boldsymbol{Z}$ & $\boldsymbol{p}$ \\
\hline Effect on chemistry achievements & 78 & 17 & 3 & & \\
Effect on interest & 78 & 17 & 3 & & \\
\hline
\end{tabular}

Note. *Three teachers did not complete the survey.

Although there were no statistically significant differences $(Z=-.325 ; p=$ .745) between teachers' assessments of the impact of chemistry demonstrations on students' performance in chemistry and motivation to learn it, the results show that teachers assess a slightly greater effect of demonstration experiments on students' performance $(M e=17 ; I Q R=3)$ than on their motivation to learn chemistry $(\mathrm{Me}=$ $17 ; \quad I Q R=3$ ). Teachers' responses gave results similar to those in the literature, where 
teachers participating in the study said that demonstrations had a positive effect on students' practical work, their exam results, their understanding of chemistry concepts and their motivation for homework and laboratory work (Price \& Brooks, 2012).

The authors attributed the effects of demonstration experiments to the performance of the students much more than the effects on motivation, which is also in line with the results of our research.

Similar results were found by Basheer, Hugerat, Kortam, and Hofstein (2017), who also believe that demonstrations, if done correctly, increase students' understanding of certain chemical phenomena, their motivation and their interest in learning chemistry.

The third research question was: 'Do chemistry teachers with different lengths of teaching experience have significantly different opinions about the impact of chemistry demonstrations on students' knowledge of chemistry?' In this case, the teachers had to give their agreement to four statements using a 5-point Likert scale according to their years of experience in teaching chemistry, teachers were divided into three groups: (1) 1-5 years, (2) 6-15 years and (3) more than 15 years.

Table 5

Teachers' opinions on the impact of chemistry demonstrations on students' chemistry knowledge based on their years of experience in teaching chemistry.

\begin{tabular}{|c|c|c|c|c|c|c|}
\hline Statement & $\begin{array}{l}\text { Years of experience in } \\
\text { teaching chemistry }\end{array}$ & $N$ & $\bar{R}$ & $x^{2}$ & $d f$ & $p$ \\
\hline \multirow{4}{*}{$\begin{array}{l}\text { Chemistry demonstrations help } \\
\text { students to make links between } \\
\text { the three levels of chemical rep- } \\
\text { resentation (macro, sub-micro } \\
\text { and symbolic representation. }\end{array}$} & $1-5$ years & 12 & 40.8 & \multirow{4}{*}{.681} & \multirow{4}{*}{2} & \multirow{4}{*}{.711} \\
\hline & $6-15$ years & 20 & 42.3 & & & \\
\hline & more than 15 years & 46 & 37.6 & & & \\
\hline & Total & 78 & & & & \\
\hline \multirow{4}{*}{$\begin{array}{l}\text { Chemistry demonstrations in- } \\
\text { crease students' confusion about } \\
\text { abstract chemical concepts. }\end{array}$} & $1-5$ years & 12 & 46.9 & \multirow{4}{*}{1.972} & \multirow{4}{*}{2} & \multirow{4}{*}{.373} \\
\hline & $6-15$ years & 20 & 40.4 & & & \\
\hline & more than 15 years & 46 & 37.2 & & & \\
\hline & Total & 78 & & & & \\
\hline \multirow{4}{*}{$\begin{array}{l}\text { Chemistry demonstrations } \\
\text { help the students to relate the } \\
\text { particle nature of matter to the } \\
\text { observations of the demonstra- } \\
\text { tion. }\end{array}$} & $1-5$ years & 12 & 38.7 & \multirow{4}{*}{.069} & \multirow{4}{*}{2} & \multirow{4}{*}{.966} \\
\hline & $6-15$ years & 20 & 38.8 & & & \\
\hline & more than 15 years & 46 & 40.0 & & & \\
\hline & Total & 78 & & & & \\
\hline \multirow{4}{*}{$\begin{array}{l}\text { Chemistry demonstrations de- } \\
\text { velop the students' curiosity to } \\
\text { learn more about chemistry. }\end{array}$} & $1-5$ years & 12 & 35.3 & \multirow{4}{*}{1.390} & \multirow{4}{*}{2} & \multirow{4}{*}{.499} \\
\hline & $6-15$ years & 20 & 37.5 & & & \\
\hline & more than 15 years & 46 & 41.5 & & & \\
\hline & Total & 78 & & & & \\
\hline
\end{tabular}


There are no significant differences between teachers with different experience in teaching chemistry and their agreement with the following statements: 1) 'Demonstrations help students make links between the "three levels" of chemistry representation (macro, sub-micro and symbolic representation), $\left(\chi_{2}^{2}=0.681\right.$; $d f=2 ; p=.711) ; 2$ ) 'Demonstrations increase students' confusion about abstract chemistry concepts', $\left.\left(\chi^{2}=1.972 ; d f=2 ; p=.373\right) ; 3\right)$ 'Demonstrations help students relate the particle nature of matter to the observations in the demonstration', ( $\chi^{2}$ $=0.069 ; d f=2 ; p=.966) ; 4)$ 'Demonstrations develop in students a curiosity to know more about chemistry', $\left(\chi^{2}=1.390 ; d f=2 ; p=.499\right)$. Although there are no significant differences between the teachers, we can say that most of them agree with all statements, regardless of their teaching experience.

The fourth research question was: 'Do chemistry teachers who conduct a varying number of chemistry demonstrations in their classes evaluate the impact of chemistry demonstrations on student performance and interest in chemistry education significantly differently?.' Teachers were divided into three groups according to how often they carry out demonstrations, and the answers to four items from the questionnaire were totalled to determine their opinion about the effects of demonstration experiments on students' performance in chemistry and their impact on students' interest in learning chemistry. Teachers expressed their opinions on the impact of demonstration experiments on the quality of the homework done and the practical work of the students, the results of the students' knowledge tests, and their level of knowledge of chemical concepts.

\section{Table 6}

Teachers' assessments of the impact of chemistry demonstrations on student performance in chemistry and interest in learning chemistry based on the frequency with which teachers conduct chemistry demonstrations.

\begin{tabular}{|c|c|c|c|c|c|c|}
\hline & $\begin{array}{l}\text { Frequency of performing demonstra- } \\
\text { tion experiments }\end{array}$ & $N$ & $\bar{R}$ & $x^{2}$ & $d f$ & $p$ \\
\hline \multirow{4}{*}{$\begin{array}{l}\text { Effect on } \\
\text { chemistry } \\
\text { achievements }\end{array}$} & Rarely or approx. once a month & 9 & 32.7 & \multirow{4}{*}{2.550} & \multirow{4}{*}{2} & \multirow{4}{*}{$.27 \varsigma$} \\
\hline & Twice or three times a month & 37 & 34.4 & & & \\
\hline & Once, twice or three times a week & 27 & 42.1 & & & \\
\hline & Total & 73 & & & & \\
\hline \multirow{4}{*}{$\begin{array}{l}\text { Effect on } \\
\text { interest }\end{array}$} & Rarely or approx. once a month & 9 & 38.8 & \multirow{4}{*}{4.463} & \multirow{4}{*}{2} & \multirow{4}{*}{.107} \\
\hline & Twice or three times a month & 37 & 31.6 & & & \\
\hline & Once, twice or three times a week & 26 & 42.7 & & & \\
\hline & Total & 72 & & & & \\
\hline
\end{tabular}


The Kruskal-Wallis Test showed no significant differences between teachers with different frequencies of conducting chemistry demonstrations and their assessments of the impact of chemistry demonstrations on student performance in chemistry $\left(\chi^{2}=2.550 ; d f=2 ; p=.279\right)$. In the sample, teachers who conduct chemistry demonstrations two or three times a month estimated that chemistry demonstrations have a more positive effect on both chemistry performances than teachers who conduct chemistry demonstrations rarely or about once a month and once, twice or three times a week.

There were also no significant differences between teachers with different frequencies of conducting chemistry demonstrations and their assessments of the impact of chemistry demonstrations on students' interest in learning chemistry $\left(\chi_{2}=4.463 ; d f=2 ; p=.107\right)$. In the sample, teachers who conduct chemistry demonstrations once, twice or three times a week estimated that chemistry demonstrations have a more positive effect on both students' performances in chemistry than teachers who conduct chemistry demonstrations rarely or about once a month and twice or three times a month.

In summary, no matter how often teachers conduct chemistry demonstrations, there is no difference in their assessments of how demonstration experiments contribute to students' interest and achievement in chemistry, which can mean that the effect is always the same, regardless of how often they perform chemistry demonstrations. However, average rankings show that teachers who conduct chemistry demonstrations attribute a slightly greater effect to student performance and motivation to chemistry demonstrations.

\section{Conclusions}

The results show that most teachers involve their students in chemistry demonstrations by asking them to write down, comment on, and/or explain their observations, followed by the students who observe the experiment.

The results show that there are no significant differences between teachers' assessments of the effect of chemistry demonstration on performance in chemistry and students' interest in chemistry lessons. The impact of the chemistry demonstration experiments on the students' performance became almost as important as their impact on the students' interest.

The results show that there are no significant differences between teachers with different lengths of teaching experience with regard to their opinions on the effects of chemistry demonstrations on the students' chemistry knowledge. Despite their different lengths of teaching experience, most teachers agreed with the statements of the questionnaire. However, the results also show 
that a larger proportion of teachers, especially senior teachers, should have considered that demonstration experiments have a positive effect on the quality of the students' chemical knowledge. From this perspective, it is important to provide continuous training for teachers so that the quality and frequency of chemistry demonstrations remains high and in line with recent trends in education. Only in this manner can teachers can influence the quality of students' chemical knowledge through chemistry demonstrations.

The results show that there are no significant differences between teachers who conduct a varying number of chemistry demonstrations in their classes on the impact of chemistry demonstrations on student performance and interest in learning chemistry. Teachers who frequently (once, twice or three times a week) conduct demonstration experiments believe that demonstrations have a greater impact on students' performance in chemistry and their interest in learning chemistry.

In summary, it can be said that the more often teachers conduct chemistry demonstrations in their classes, the more motivated and successful the students are in chemistry lessons. It is also logical that teachers who conduct chemistry demonstrations less frequently or not at all find that the motivation and performance of the students are not affected by the chemistry demonstrations. The reason for such an assessment may be that they have carried out chemistry demonstrations in the past and have seen that they do not influence the interest and performance in chemistry, or they do not know what effect demonstration experiments would have if they were carried out frequently and, above all, pedagogically correctly.

\section{Limitations of the research}

Based on the research design, the following limitations can be identified: 1) small sample of participating teachers, 2) some of the teachers participating in the research did not complete the questionnaire, 3 ) it is not possible to obtain data on the students' chemistry achievements, their interest in learning chemistry and the impact of conducting chemistry demonstrations, and 4) it is difficult to assess the actual course of chemistry teaching on the basis of the questionnaire because the respondents' teaching was not systematically monitored.

\section{Application for chemical education}

On the basis of the research results, some guidelines for the implementation of the findings in the educational process can be introduced. It is necessary to emphasise the importance of experimental work and thus of chemistry demonstrations in courses at the university during pre-service chemistry teacher 
education. This would require the preparation of materials and e-units to help in-service and pre-service teachers to prepare and conduct chemistry demonstrations in their classes. It is also important to involve teachers in projects that explore new principles and the ways of conducting chemistry demonstrations in schools, such as the SQER 3 model proposed by Chamely-Wiik et al. (2014). Professional development programmes are also important for teachers currently teaching in schools and who have not been able to acquire this knowledge during their studies, as trends in the educational process change and improve. Such programs would introduce teachers to the importance of demonstration experiments to develop high quality chemical knowledge and to motivate students, as well as to ways of implementation, with particular emphasis on inquiry-based learning.

\section{Guidelines for further research}

It would be highly advisable to obtain a slightly larger sample of teachers in the course of further research, which would show a somewhat more realistic situation regarding the use of chemistry demonstrations in Slovenian primary and secondary schools. A similar questionnaire would also be given to the students of the participating teachers to see how their views and opinions on chemistry demonstrations in chemistry lessons differ. In addition, teachers should be observed in class to determine how they teach, what demonstrations they give, when they give them and how often. It would also be helpful to implement different approaches to experimental work in the classroom and to identify those that have a greater impact on students' interest in learning chemistry and their achievements.

\section{References}

Ashkenazi, G., \& Weaver, G. C. (2007). Using lecture demonstrations to promote the refinement of concepts: the case of teaching solvent miscibility. Chemistry Education Research and Practice, 8(2), $186-196$.

Basheer, A., Hugerat, M., Kortam, N., \& Hofstein, A. (2017). The effectiveness of teachers' use of demonstrations for enhancing students' understanding of and attitudes to learning the oxidationreduction concept. Eurasia Journal of Mathematics, Science and Technology Education, 13(3), 555-570. Beall, H. (1996). Report on the WPI Conference" demonstrations as a teaching tool in chemistry: Pro and con". Journal of chemical education, 73(7), 641-642.

Bodner, G. M. (2001). Why lecture demonstrations are 'exocharmic' for both students and their instructors. University Chemistry Education, 5(1), 31-35.

Buncick, M. C., Betts, P. G., \& Horgan, D. D. (2001). Using demonstrations as a contextual road map: 
enhancing course continuity and promoting active engagement in introductory college physics. International Journal of Science Education, 23(12), 1237-1255.

Chamely-Wiik, D. M., Haky, J. E., Louda, D. W., \& Romance, N. (2014). SQER3: An instructional framework for using scientific inquiry to design classroom demonstrations. Journal of Chemical Education, 91(3), 329-335.

Haagen-Schützenhöfer, C., \& Joham, B. (2018). Professionalising physics teachers in doing experimental work. Center for Educational Policy Studies Journal, 8(1), 9-34.

Hodson, D. (1990). A critical look at practical work in school science. School Science Review, 7o(256), $33-40$.

Hodson, D. (1993). Re-thinking old ways: Towards a more critical approach to practical work in school science. Studies in Science Education, 22(1), 85-142.

Hofstein, A. (2015). Laboratory Work, Forms of. Encyclopedia of Science Education, 563-566. Johnstone, A. H. \& Al-Shuaili, A. (2001). Learning in the laboratory; some thoughts from the literature. University Chemistry Education, 5(2), 42-51.

Kelter, P. (1994). Are our demonstration-based workshops doing more harm than good? Journal of Chemical Education, 71(2), 109-110.

Logar, A., \& Savec, V. F. (2011). Students' hands-on experimental work vs lecture demonstration in teaching elementary school chemistry. Acta Chimica Slovenica, 58(4), 866-875.

Meyer, L. S., Panee, D., Schmidt, S., \& Nozawa, F. (2003). Using demonstrations to promote student comprehension in chemistry. Journal of Chemical Education, 8o(4), 431-435.

Moore, J. W. (2000). Enthusiastic teachers, vivid experiments. Journal of Chemical Education, $77(4)$, 429 .

Pavlin, J., Glažar, S. A., Slapničar, M., \& Devetak, I. (2019). The impact of students' educational background, interest in learning, formal reasoning and visualisation abilities on gas context-based exercises achievements with submicro-animations. Chemistry Education Research and Practice, 2o(3), 633-649.

Price, D. S., \& Brooks, D. W. (2012). Extensiveness and perceptions of lecture demonstrations in the high school chemistry classroom. Chemistry Education Research and Practice, 13(4), 420-427. Trowbridge, L., Bybee, R., \& Powell, J. (2000). Teaching secondary school science: Strategies for developing scientific literacy. Pearson.

Tsaparlis, G. (2009). Learning at the macro level: The role of practical work. In J. K. Gilbert \& D. Treagust (Eds.), Multiple representations in chemical education, models and modeling in science education (pp. 109-136). Springer.

Waldman, A. S., Schechinger, L., \& Nowick, J. S. (1996). A coordinated chemistry outreach program for thousands of high school students. Journal of Chemical Education, 73(8), 762-764.

Walton, P. H. (2002). On the use of chemical demonstrations in lectures. University Chemistry

Education, 6(1), 22-27.

White, R. T. (1996). The link between the laboratory and learning. International Journal of Science Education, 18(7), 761-774. 
Wissiak-Grm, K. S., \& Glažar, S. A. (2002). Pomen eksperimentalnega dela pri učenju in poučevanju kemije v osnovni šoli [The importance of experimental work in learning and teaching chemistry in primary school]. Sodobna pedagogika, 53(2), 96-106.

Zimrot, R., \& Ashkenazi, G. (2007). Interactive lecture demonstrations: a tool for exploring and enhancing conceptual change. Chemistry Education Research and Practice, 8(2), 197-211.

\section{Biographical note}

LUKA Vinko is a teaching assistant in the field of chemical education at the University of Ljubljana, Faculty of Education, Slovenia. His research interests include experimental work in chemistry classes in primary and secondary school.

Seamus Delaney, PhD, is a lecturer in the field of didactics of science at the Faculty of Arts and Education, Deakin University, Australia. His research interests include teaching and learning in chemistry, science education in out-of-school/informal learning contexts, systems thinking to address socio-scientific issues in chemistry, teacher education and their professional development.

IzTok Devetak, PhD, is Full Professor of Chemical Education at University of Ljubljana, Faculty of Education, Slovenia. His research focuses on students' chemistry learning and their motivation, how chemistry in context stimulates learning using eye-tracking technology in explaining science learning, aspects of environmental education, and the development of teachers' health-managing competences. 